\title{
Long-standing malignant pancreatic carcinoid treated with octreotide
}

\author{
M. J. Varas-Lorenzo \\ Unidad de Ecoendoscopia y Eco-Doppler. Centro Médico Teknon. Barcelona, Spain
}

\begin{abstract}
A male presented with a metastatic, plasma serotonin-secreting (high 5-HIAA in urine), malignant pancreatic carcinoid with a carcinoid-like syndrome, and was assessed using ultrasounds (US), computerized tomography (CT), magnetic resonance imaging (MRI), endoscopic ultrasonography (EUS) and Octreoscan; he sequentially received chemotherapy, interferon and octreotide, with long-term, 12-year survival after diagnosis. Given this unusual case, the second reported in our country, the overall literature is reviewed.
\end{abstract}

Key words: Pancreatic carcinoid. Serotoninoma. Apudoma or neuroendocrine pancreatic tumor. Serotonin. 5-Hydroxyndoleacetic acid (5-HIAA). Octreotide.

\section{RESUMEN}

Se presenta un varón con un carcinoide pancreático maligno, con metástasis, secretor de serotonina plasmática (5-HIAA urinario elevado) con síndrome carcinoide-like, evaluado mediante ecografía (US), tomografía computarizada (TAC), resonancia magnética (RM), ultrasonografía endoscópica (USE) y Octreoscan, tratado con quimioterapia, Interferón y Octeotrida, de forma secuencial, con supervivencia prolongada de 12 años después del diagnóstico.

A propósito de este caso inusual, el segundo publicado desde nuestro país, se revisa la literatura mundial.

Palabras clave: Carcinoide pancreático. Serotoninoma. Apudoma o tumor neuroendocrino pancreático. Serotonina. Ácido 5hidroxindolacético (5-HIAA). Octeotrida.

Received: $12-04-10$.

Accepted: 15-04-10.

Correspondence: M. J. Varas-Lorenzo. Centro Médico Teknon. Marquesa de Vilallonga, 12, 08017 Barcelona, Spain.e-mail: varas@dr.teknon.es
Varas Lorenzo MJ. Long-standing malignant pancreatic carcinoid treated with octreotide. Rev Esp Enferm Dig 2010; 102: 662-665.

\section{INTRODUCCIÓN}

Carcinoid tumors (CTs) represent the most common neuroendocrine tumors (NETs). They are usually located in the thorax and gastrointestinal tract (1); their location within the biliary system (common bile duct), papilla and pancreas is exceptional. Pancreatic CTs are usually malignant (2) and have a poorer prognosis. The rate of pancreatic carcinoids is likely lower than $1 \%$ of all carcinoids. We report the case of an Octreoscan-positive malignant pancreatic CTs with metastases and carcinoidlike syndrome that was treated with interferon (3) and octreotide (4), and showed prolonged survival for over 10 years.

\section{CASE REPORT}

A 53-year-old male in 1985, smoker, suffering from pain and diarrhea for the last six years and potential chronic pancreatic disease, underwent laparotomy because of a pancreatic growth in the body and uncinate process (biopsy: pancreatic carcinoid) and a second mass at the root of the mesocolon. Following the procedure, through 1996, he kept suffering from abdominal pain, chronic diarrhea, steatorrhea, tearing, and mild flush (carcinoid-like syndrome). He also developed 
cholelithiasis, skin pigmentation and exophthalmos. He died 12 years after diagnosis and 18 years after initial symptoms from ascites, overall metastatic disease, and multiple organ failure. Following laparotomy, he received chemotherapy with streptozotocin plus 5-fluorouracil $(\mathrm{STZ}+5$-FU) for 6 weeks, octreotide and interferon alfa- $2 b$.

Interferon alfa- $2 \mathrm{~b}$ at $3 \mathrm{MU} /$ day/3 days (induction) and at $5 \mathrm{MU}$ three times a week for 5 months resulted in no tumor or biochemical response. The patient had to discontinue therapy because of mild flu-like syndrome, leukopenia, and low platelet count (3). Octrotide as chronic therapy at 50-100 $\mu \mathrm{g} / 12 \mathrm{hrs}$ resulted in clinical and biochemical responses, although, as adverse event, he developed BL and repeat biliary colics (4).

Laboratory tests were normal except for hypocholesterolemia. Hyperthyroidism, hemochromatosis, and Cushing syndrome were ruled out. Hormonal tests: serotonin, $2125 \mathrm{ng} / \mathrm{ml}$ (62-159). Gastrin, $29 \mathrm{pg} / \mathrm{ml}$ (< 100). Insulin, $11 \mu \mathrm{U} / \mathrm{ml}$ (5-20). Glucagon, 117 and 149

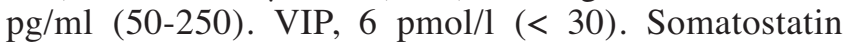
(SMS), $20 \mathrm{pg} / \mathrm{ml}$ (10-25). Neuron-specific enolase (NSE), $2.2 \mathrm{ng} / \mathrm{ml}(<13)$. Prostaglandin $(\mathrm{PGE}),<4.3$ $\mathrm{pg} / \mathrm{ml}$. ACTH, $22 \mathrm{pg} / \mathrm{ml}(\mathrm{N}<70)$. CEA, $1.5 \mathrm{ng} / \mathrm{ml}(<$ $6)$. Catecholamines and metanephrines in 24-h urine were normal. Urine 5-HIAA ( $\mathrm{N}:<12 \mathrm{mg} / 24 \mathrm{hr}), 44$ $\mathrm{mg} / 24 \mathrm{hr}$ (1986). Urine 5-HIAA (N: $<10 \mathrm{mg} / 24 \mathrm{hr}$ ), $119.7 \mathrm{mg} / 24 \mathrm{hr}$. Serotonin, $1100 \mathrm{ng} / \mathrm{ml}$ (50-300) (1992). Urine 5-HIAA ( $\mathrm{N}:<10 \mathrm{mg} / 24 \mathrm{hr}), 147.8 \mathrm{mg} / 24$ $\mathrm{hr}$ at baseline; at 2 months 66.6 and at 1 year $6 \mathrm{mg} / 24$ hr post-octreotide for 12 months at the above doses. Fat in stool: in 1988, > $8 \mathrm{gr} / 24 \mathrm{hr} ; 9.8 \mathrm{gr} / 24 \mathrm{hr}$. In 1992, 20 $\mathrm{gr} / 100 \mathrm{gr}$ weight and day; $38 \mathrm{gr} / 100 \mathrm{gr}$ weight and day. Fat in stool turned to normal amount after oral administration of pancreatic enzymes (5).

Imaging (Figs. 1-4): Computerized tomography (CT) (1985) and ultrasound (US): hypodense, hypoechoic 2 -cm mass in the pancreas. Liver metastasis (5

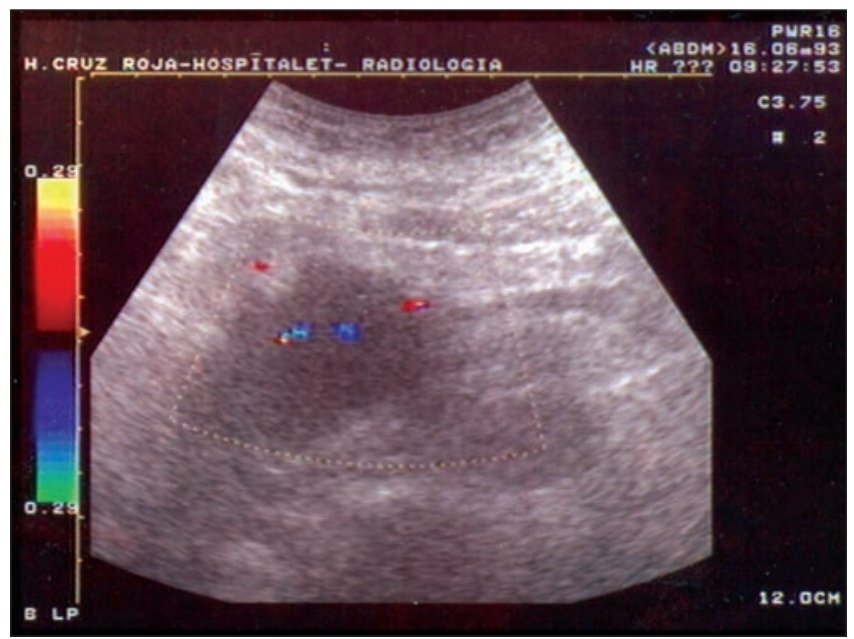

Fig. 1. US: Sagittal and transverse sonographic sections $(3.5 \mathrm{MHz})$ of this hypoechogenic pancreatic tumor.

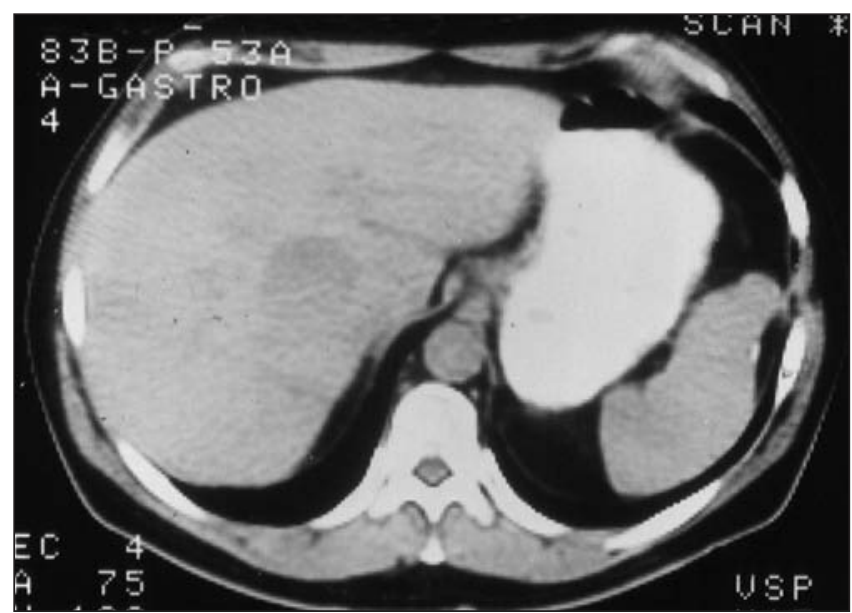

Fig. 2. CT: Hypodense liver metastasis.

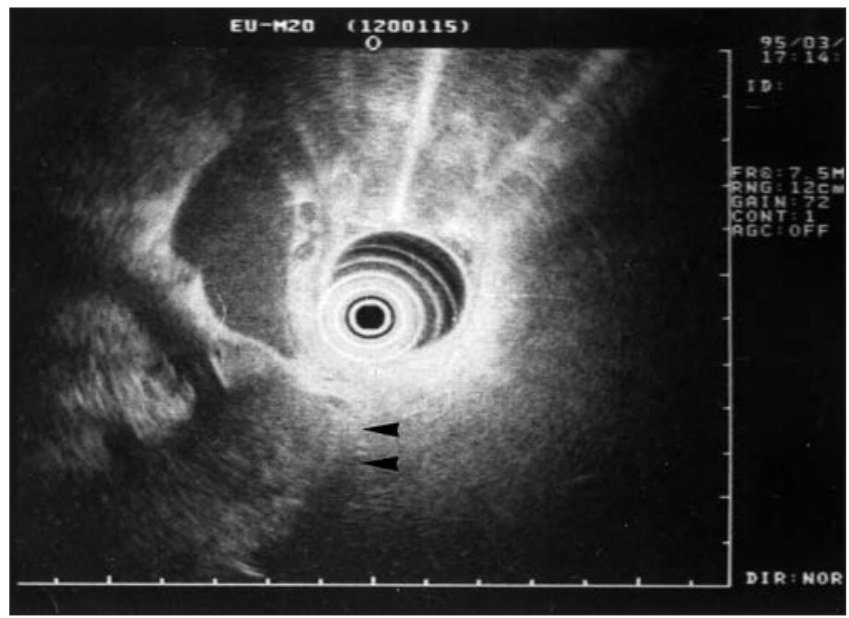

Fig. 3. EUS: A pancreatic carcinoid (below, two arrows) compressing a widely dilated bile duct with lithogenic bile and biliary mud, as well as the portal vein.

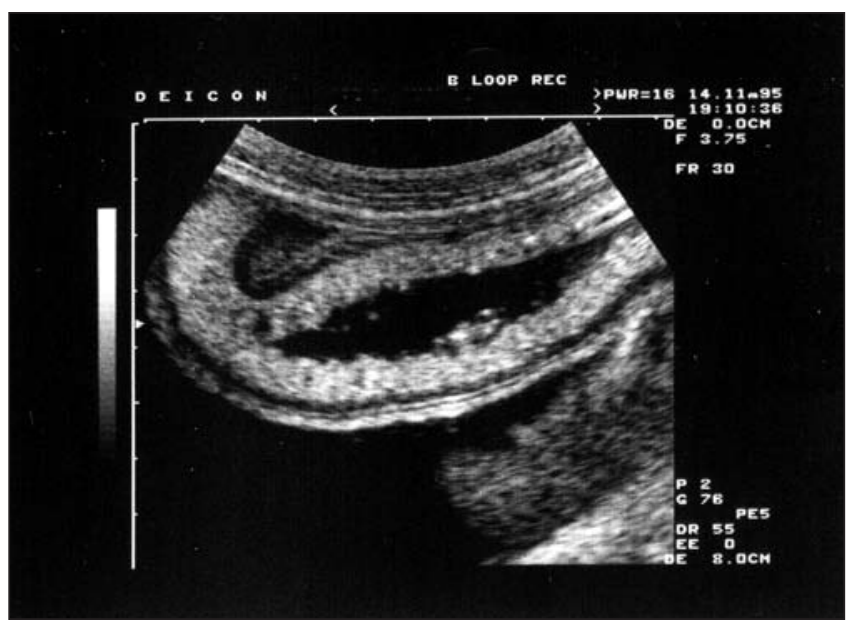

Fig. 4. US: Abdominal section (3.75 MHz) showing ascites, mesenteric infiltration, and intestinal wall hypertrophy at the expense of the mucosa and submucosa. The dual muscularis propria and serosal layers are finely delimited as though with EUS. 
$\mathrm{cm})$ at the caudate with mild contrast uptake. Magnetic resonance imagen: same diagnosis. Endoscopic ultrasound (EUS) (1987): heart valve calcification, liver metastasis, no pancreatic mass can be detected because patient was intolerant to examination. Cranial CT: Normal. CT $(1989,1992)$ : Two metastases of 1 and 8 $\mathrm{cm}$ in the right and caudate lobes; hypodense growth in head-body. All this images were greater in size as compared to previous workup in 1985. US (1990): Two echogenic metastases of 1 and $6 \mathrm{~cm}$; BL; hypoechogenic growth $26-30 \mathrm{~mm}$ in size. Color Doppler US (1993), non vascularized echogenic metastases. No portal thrombosis. Octreoscan (1995), positive for liver metastasis and pancreatic tumor (hyperactive). EUS (1995): BL and hypoechogenic pancreatic mass dilating the common bile duct and portal vein. US (1995), ascites, BL, metastases, 39 and $65 \mathrm{~mm}$ in size, and pancreas tumor greater than $30 \mathrm{~mm}$ that was dilating bile duct system and Wirsung $(3.6 \mathrm{~mm})$. Thickened intestinal wall. Bowel follow-through (1995): mesenteritis.

\section{DISCUSSION}

Formerly, the term pancreatic carcinoid tumor was considered similar to pancreatic islet cell tumor or to pancreatic neuroendocrine tumor. Currently, pancreatic carcinoid is considered the pancreatic serotoninome or endocrine tumor of the pancreas secreting serotonine. The first reported cases of pancreatic carcinoid date back to the 1960s and 70s. The first case ever reported is likely the one by Pataky et al. in 1959 (6). Through 1963, only 13 cases had been reported (7), and until 1983, we reviewed 25 cases. Patchefsky et al. (8) reported 4 cases of endocrine pancreatic tumors with high urine 5-HIAA. In 1986, the first case associated with multiple endocrine neoplasm (MEN-1) was reported (9), though cases with multiple hormone secretion (MHS) had been previously found.

Clinical manifestations of pancreatic carcinoid include abdominal pain, diarrhea, and weight loss, with typical CS from 5-hydroxytryptamine (serotonin) production or atypical CS from serotonin precursor 5-hydroxytryptophan. Cases had been reported that caused acute or chronic pancreatitis $(10,11)$. Our patient presented with all these abnormalities in addition of steatorrhea from potential exocrine pancreatic deficiency that was treated with oral pancreatic enzymes (5); exocrine pancreatic insufficiency has also been associated with gastrinoma, somatostatinoma (12) and carcinoid (13).

In 1996 (14), in connection with a case, 29 patients reported between 1966 and 1995 were reviewed. Tumors had a mean diameter of $4 \mathrm{~cm}$, many had multiple hormone secretion with atypical carcinoid syndrome, there was flush in only $34 \%$, and $69 \%$ were malignant. High urine 5-HIAA was seen in $85 \%$ of cases, and $100 \%$ showed serotonin-positive immunocytochemistry. In 1998 (16), two additional cases are reported and 43 patients are reviewed. Eighty eight percent of cases were malignant with poor prognosis. Modlin and Sandor (15) estimated US frequency as $0.55 \%, 0.58 \%$ of all carcinoid tumors, with 5-year survival between $34 \%$ (17) and 37.5\% (18). Soga (19) reviewed $156 / 11.343$ cases of carcinoid $(1.4 \%)$ and compared them to 165 reported worldwide. Most (66.7\%) tumors were malignant and $23 \%$ of them had CS; $93 \%$ showed serotonin-positive immunohistochemistry, and the 5year survival was low at $29 \%$. Waisberg et al. (20) estimated its frequency below $1 \%$, being a rarity in children and young adults. In our recently reported series of carcinoids, frequency is $2 \%$ (21). Bilimoria et al., in 2007 (22), estimated frequency to be $7.9 \%$ of pancreatic endocrine tumors (PETs). They mostly presented at a mean age of 63 years in Caucasian individuals of both sexes, and metastases developed in $63.5 \%$. A recent Chinese series reported 8 cases in 2009 (23) with a mean age of 37 years (range 8 to 52). Fifty percent of patients were females; radical surgery was performed in $62.5 \%$ with a good outcome in four, despite the fact that $37.5 \%$ had liver mestastases and metastatic disease was unveiled in $50 \%$.

Location is usually established by using US/CT/MRI (24-27), but some cases have been localized with EUS (28-30) and Octreoscan (31). The exact role PET-CT may play is currently unknown. On ultrasonograms, pancreatic carcinoids are usually hypoechogenic and, when located in the head, originate in bile system dilation, as was our case. CT shows hypodense, homogeneous growths when small, or heterogeneous masses with cystic necrosis areas when large (25). In our case, diagnostic images were taken using US/CT/MRI/EUS/Octreoscan (Figs. 1-4). The last sonogram identified dilation of the common pancreatic duct (Wirsung), as recently reported $(26,27)$, as well as thickened intestinal wall and ascites.

Ideal therapy consists of surgical resection with curative intent, which at times is not feasible because of malignity and frequency of metastases. However good response rates have been reported with octreotide (32), as it was in our case. Chemo-radiotherapy, primary tumor resection and liver transplantation are option in cases of metastatic disease (33). Chemoembolization (34) and medical management with somatostatin analogs and interferon are also useful, as is the treatment with In111-DTPA $(35,36)$. Our patient clinically and biochemically responded to acute and chronic therapy with octreotide.

Over 200 cases of pancreatic carcinoids have most likely been reported as of today; the following ensues from a literature review (Table I) (16): a) pancreatic carcinoid or serotoninoma secretes and releases sero- 
Table I. Literature summary

\begin{tabular}{lll}
\hline Pataky (6) & & First case reported \\
Hiller (7) & $1959-1963$ & 13 cases reviewed \\
Patchefsky (8) & & 4 cases reported \\
Varas & $1963-1983$ & 25 cases reviewed \\
Maurer (14) & $1966-1995$ & 29 cases reviewed and 1 new case reported \\
Mao (16) & through 1998 & 43 cases including two new ones \\
Modlin (17) & $1950-1999$ & 79 cases reviewed in USA \\
Soga (19) & 2005 & 156 cases reviewed in Japan vs. 165 worldwide \\
Pérez-Fidalgo (33) & 2006 & 1 case report in our country \\
He (23) & 2009 & 8 cases reported and reviewed \\
\hline
\end{tabular}

tonin (5-HIAA in urine), since it is made up of EC cells (argyrophilia) within the pancreas, with positive immunohistochemistry for said hormone; b) tumors are malignant in about $70 \%$ of cases, and present with either typical or atypical CS (fewer than 50\%) as well as a triad of abdominal pain, diarrhea, and weight loss; c) survival at 5 years is low, around $30 \%$, but may respond to somatostatin analogs and radical surgery; d) frequency is around $1 \%$ of all carcinoids, and 10-year survival is $10 \%$ (35) because of high malignant potential (36); e) they may be associated with MHS, MEN-1 (9), and gastroduodenal carcinoids (37); and f) in contrast to pancreatic carcinoids, carcinoids in the common bile duct and minor papilla are extremely rare $(8$ cases reported), and those of the papilla are rare (70 cases reported) (38).

\section{REFERENCES}

1. Kulke MH, Mayer RJ. Carcinoid tumors. New Engl J Med 1999; 340: 858-68.

2. Metz DC, Jensen RT. Gastrointestinal neuroendocrine tumors: pancreatic endocrine tumors. Gastroenterology 2008; 135: 146992.

3. Varas MJ, Gordillo J. Tumores pancreáticos endocrinos y terapia con interferón alfa 2b. Gastroenterol y Hepatol 1992; 15: 393-6.

4. Varas MJ, Tortosa F. Tumores endocrinos gastroenteropancreáticos y tratamiento con octreótida. Cir Esp 1995; 58: 325-8.

5. Varas MJ, López A. Esteatorrea y su tratamiento con fermentos pancreáticos en los tumores endocrinos del páncreas (apudomas pancreáticos). Rev Esp Enferm Dig 1990; 78: 27-30.

6. Pataky Z, Nagy L, Popik E. On a case of primary argentaffin tumor arising from the pancreas head. Zentralbl Allg Pathol 1959; 99: 442-4.

7. Hiller N, Berlowitz D, Fisher D, Blinder G, Hadas-Halpern I. Primary carcinoid tumor of the pancreas. Abdom Imaging 1998; 23: 188-90.

8. Patchefsky AS, Solit R, Phillips LD, et al. Hydroxyndole-producing tumors of the pancreas. Carcinoid-islet cell tumor and oat cell carcinoma. Ann Intern Med 1972; 77: 53-61.

9. Lee CH, Ching KN, Lui WY, et al. Carcinoid tumor of the pancreas causing the diarrheogenic syndrome: a report a case combined with multiple endocrine neoplasia, type I. Surgery 1986; 99: 123-9.
10. Gettenberg G, Zimbalist E, Marini C. Chronic pancreatitis and pseudocyst formation secondary to carcinoid tumor of the pancreas, Gastroenterology 1988; 94: 1222-4.

11. Nagai E, Yamaguchi K, Hashimoto H, Sakurai T. Carcinoid tumor of the pancreas with obstructive pancreatitis. Am J Gastroenterol 1992; 87: 361-4.

12. Garcia-Borobia F, Fabregat J, Jorba R, Poves I, Biondo S, et al. Exocrine pancreatic insufficiency caused by somatostatinoma of the minor and major duodenal papilla in a patient with neurofibromatosis. Eur J Surg 2001; 167: 154-6.

13. Waisberg J, de Matos LL, Waisberg DR, et al. Carcinoid of the minor duodenal papilla associated with pancreas divisum: a case report and review of literature, Clinics 2006; 61: 365-8.

14. Maurer CA, Baer HU, Dyong TH, et al. Carcinoid of the pancreas: clinical characteristics and morphological features. Eur J Cancer 1996; 32A: 1109-16.

15. Modlin IM, Sandor A. An analysis of 8.305 cases of carcinoid tumors. Cancer 1997; 15: 813-29.

16. Mao C, El Attar A, Domenico DR, Kim K, Howard JM. Carcinoid tumors of the pancreas. Status report based on two cases and review of the world's literature. Int J Pancreatol 1998; 23: 15364

17. Modlin IM, Lye KD, Kidd M. A 5-decade analysis of 13.715 carcinoid tumors. Cancer 2003; 97: 934-59.

18. Modlin IM, Shapiro MD, Kidd M. An analysis of rare carcinoid tumors: clarifying these clinical conundrums. World J Surg 2005; 29: 92-101.

19. Soga J. Carcinoids of the pancreas: an analysis of 156 cases. Cancer 2005; 104: 1180-7.

20. Waisberg J, de Matos LL, Drom dos Santos HV, et al. Pancreatic carcinoid: a rare cause of diarrheogenic síndrome. Clinics 2006; 61: 175-8.

21. Varas MJ, Muñoz F, Espinós JC, Bardají M. Tumores carcinoides digestivos. Rev Esp Enferm Dig 2010; 102(9): 533-7.

22. Bilimoria KY, Tomlinson JS, Merkow RP, et al. Clinicopathologic features and treatment trends of pancreatic neuroendocrine tumors: analysis of 9821 patients. J Gastrointest Surg 2007; 11: 1460-9.

23. He X-W, Wu X-J, He X-S, Zou Y, Ke J, Wang J, Lan P. Clinicopathologic analysis of eight cases of pancreatic carcinoid tumors. Chinese Med J 2009; 122: 1591-4.

24. Villanueva A, Pérez C, Llauger J, Traid C, Parellada JA, Puig P. Carcinoid tumors of the pancreas: CT findings. Abdom Imaging 1994; 19: 221-4

25. Dahan H, Soyer P, Cochand-Priollet B, et al. Imagerie des tumeurs carcinoides primitives du pancreas. J Radiol 2001; 82: 987-90.

26. Takaji R, Matsumoto S, Mori $\mathrm{H}$, et al. Carcinoid tumors of the pancreas: dynamic CT and MRI features with pathological correlation. Abdom Imaging 2009: 34: 753-8.

27. Hamada Y. Nakayama Y, Maeshiro K, et al. Two cases of primary carcinoid tumor of the páncreas associated with marked stenosis of the main pancreatic duct. Pancreas 2009; 38: 834-5.

28. Anderson MA, Carpenter S, Thompson NW, et al. Endoscopic ultrasound is highly accurate and directs management in patients with neuroendocrine tumors of the pancreas. Am J Gastroenterol 2000; 95: 2271-7.

29. Taidi C, Soyer P, Barge J, Amouyal P, Levesque M. Primary carcinoid tumor of the pancreas. X-ray computed tomographic and echo-endoscopic aspects. J Radiol 1993; 74: 347-50.

30. Saint-Marc O, Cogliandolo A, Pozzo A, Pidoto R. A primary pancreatic carcinoid tumour with unusual clinical complaints: A case report. World J Surg Oncol 2004; 2: 3-6.

31. Lobrano MB, McCarthy K, Adams L, Neitzschman H. Metastatic carcinoid tumor imaged with CT and a radiolabeled somatostatin analog: A case report. Am J Gastroenterol 1997; 92: 513-5.

32. Migliori M, Tomassetti P, Lalli S, et al. Carcinoid of the pancreas. Pancreatology 2002; 2: 163-6.

33. Pérez-Fidalgo JA, Oltra A, López A, Maestu I. Primary carcinoid tumour of the pancreas. Clin Translat Oncol 2006; 8: 54-6.

34. Gunji N, Miyamoto H, Orii K, Kawamoto T, Fukao K. Pancreatic carcinoid: transcatheter arterial chemoembolization of liver metastases. Hepatogastyroenterology 2003; 50: 2166-8.

35. Kirshbom PM, Kherani AR, Onaitis MW, et al. Foregut carci- 
noids: a clinical and biochemical analysis. Surgery 1999; 126: 1105-10.

36. Varas MJ. Neuroendocrine tumors -fascination and infrequency. Rev Esp Enferm Dig 2009; 101: 195-208.

37. Bamba T, Kosugi S, Kanda T, et al. Múltiple carcinoids in the duo- denum, páncreas and stomach accompanied with type A gastritis: A case report. World J Gastyroenterol 2007; 13: 2247-9.

38. Kim YG, Kim TN, Kim KO. Carcinoid tumor of the minor papilla in complete pancreas divisum presenting as recurrent abdominal pai. BMC Gastroenterology 2010; 10: 17-9. 